\title{
DETERMINANTS OF EFFICIENCY IN ALBANIAN BANKING INDUSTRY; AN EMPIRICAL DIAGNOSIS
}

\author{
Elona Shehu ${ }^{1}$
}

\begin{abstract}
Many articles discuss the importance of banking systems and their profitability as well as the factors determining these. This article examines the determinants of bank efficiency in the Albanian banking industry. During the second half of this decade a considerable decrease in the efficiency ratio of the Albanian banking system was evident. To understand which factors affected the efficiency, and whether Albania should control certain factors in order to improve efficiency, relationships between particular factors were analyzed using a multiple regression analysis. The study examines 16 commercial banks in Albania, from 1998 to 2015. It finds a significant relationship between efficiency, capital adequacy, the return on assets, and solvency.
\end{abstract}

JEL Classification Numbers: G32 DOI: http://dx.doi.org/10.12955/cbup.v4.749

Keywords: efficiency, solvency, leverage, performance.

\section{Introduction}

Albania is a country with a weak and undeveloped financial industry, which mainly focuses on the banking system. The current financial situation is placing commercial banks in Albania into a vicious predicament. During the recent decade, credit risk increased substantially. Consequently, when a system becomes deeply entrenched with a highly toxic and risky portfolio, the problem is usually related to asset restructuring. In such circumstances, analyzing the financial sector to determine the factors that can return the system to an efficient state is very important.

This article mainly focuses on ways of increasing the efficiency of commercial banks in Albania in order to manage their risky portfolios. The paper aims to identify the deterministic variables that significantly influence efficiency and whether restructuring of the financial system is an option or a must for reform.

The following section contains the theoretical background to the most appropriate definitions for each of the variables and the relationship between bank efficiency and degree of financial leverage, provision coverage, capital adequacy, the return on equity, and solvency. The research question and the hypothesis are established following the literature review, while the third section describes the data design and methodology for examining the hypothesis. The fourth section outlines the variables and the statistical analyses, followed by a report on the main findings. The last section of this paper contains the main concluding remarks.

\section{Literature Review}

Efficiency ratio is defined as the ability of a banking system to cover the overall expenditure, based on overall revenue for the same period. The efficiency ratio of commercial banks of Albania has fluctuated considerably over the last decade. We expect a low efficiency ratio (revenues being higher than expenses) to lead a positive indication for the banks' profitability. For this reason we expect to find a negative relationship between efficiency ratios and the return on assets (Casu \& Girardone, 2009)

Bank solvency is defined as the ability of a bank to meet its financial obligations in the short-, medium-, and long-term (Ferrouhi \& Agdal, 2014). Usually a bank is considered solvent if its assets are equal to, or exceed, its total liability. In various circumstances, the bank may be unable to pay its debt. According to Jackson, Perraudin, and Sapo (2002), solvency should be curtailed because it can lead a bank into default.

Another determinant of efficiency is capital adequacy. The relationship between profitability and financial structure has been previously studied by Petria, Capraru, and Ihnatov (2015), Berger (1995), and Pilloff and Rhoades (2002). Most of these studies have used the return on assets (ROA) as a proxy for profitability, and solvency, or capital adequacy as a proxy for financial structure.

\footnotetext{
${ }^{1}$ Elona Shehu, European University of Tirana, Tirana, Albania, elona.shehu@uet.edu.al
} 
Performance, in this context, is taken as an equivalent indicator of profitability and is defined as the ability of the company to make profits from all business activities (Owolabi \& Obida 2012). In other words, performance is an indicator of management's efficiency in using resources and adding value to the company. Owolabi, Sadiq, and Abiola (2012) found the main indicators in measuring performance were the return on investment, return on equity and ROA. In this article, ROA is used as the main proxy for identifying profitability. Further, Demirfuc and Detragiache (2005) explain that capital adequacy is the most important indicator when considering the risk of failure in a banking system.

The degree of financial leverage is an indicator strongly representing capital structure. Hughes and Mester (2008) state that in order to discuss the operational efficiency of a banking system, capital structure must be considered. Efficient banks are allowed greater flexibility by their supervisory authority for leverage and risk in general (Fiordelisi, Ibanez \& Molyneux, 2010). Berger and De Young (1997) noticed that it is very important to have empirical evidence regarding the concept of bank efficiency and its determinants; they studied the relationship of bank efficiency relating to nonperforming loans (NPLs) and capital, using the Granger causality method on a sample of US banks.

Provision coverage is the ratio of total provisions to gross NPLs (assets), and can be defined as the ability of a bank to cover loan losses. A high provision coverage ratio indicates a bank with a strong balance sheet. Therefore, we assume that an increase in provision coverage will lead to an increase in the efficiency of the bank. According to the Reserve Bank of India, commercial banks should aim for a provision ratio of about 70 per cent.

Schneide and Lenzelbaue (1993) noticed an inverse relationship between profitability and efficiency. The relationship of these two variables in bank branches has also been studied by Oral and Yolalan (1990) and Miencha and Selvam (2013), who emphasized the relationship between these variables. Meanwhile, Abbasoglu, Aysan, and Gunes (2007) failed to find any robust relationship between efficiency and profitability, and Burger and Humprey (1997) found that efficiency was more important in explaining profitability than market concentration of a financial institution.

Research Question and Hypothesis Development

Based on results of the literature review, we examine the following research question: Which determinants should commercial banks in Albania consider in order to better manage efficiency?

From this research question ensues the following hypothesis:

$\mathrm{H}$ : $\quad$ Solvency and performance are the main indicators explaining the variance of the efficiency in Albanian commercial banks.

This hypothesis will be tested, as described in the following sections.

\section{Data and Methodology}

This section describes the data collection and methodology, which involved 18 years of quarterly data. Data Design

The table below summarizes the variables, obtained from the review of literature, and their corresponding proxy. The expected relationship between the independent and dependent variable were determined by the authors listed in the table and mentioned in the literature review section. According to the information derived from the literature review and Table 1, the function of the response variable, with the explanatory variables, is as follows (Equation 1):

Efficiency $=f$ (Financial Leverage, Provision Coverage, Capital Adequacy, Return on Assets, Solvency)

Before running the regression, the variables were checked for missing values, which were omitted, leaving a sample of 67 observations. The variables were then checked for normal distribution, multicollinearity, and correlations, prior to running the regression analysis.

Figure 1 shows a comparison between normal density distribution and the Kernel density estimate for the response variable: bank efficiency. As shown in this figure, there are no large differences between the two distributions, though the Kernel estimate is slightly left skewed with a minor kurtosis. 
Table 1: Variable Description

\begin{tabular}{|c|c|c|c|c|c|}
\hline Variable & Indicator & Proxy & Abbrev. & Source & Authors \\
\hline 总 & Efficiency & $\begin{array}{l}\text { Expenses/ } \\
\text { Revenues }\end{array}$ & $\mathrm{EFF}$ & \multirow{6}{*}{$\begin{array}{l}\text { Bank of } \\
\text { Albania }\end{array}$} & $\begin{array}{l}\text { Casu and Girardone, 2009; } \\
\text { Schneide and Lenzelbaue (1993); } \\
\text { Oral and Yolalan (1990); } \\
\text { Miencha and Selvam (2013) and } \\
\text { others }\end{array}$ \\
\hline \multirow{5}{*}{ 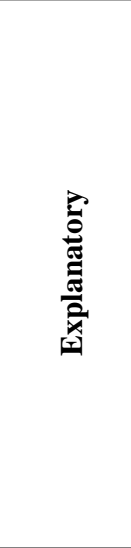 } & $\begin{array}{l}\text { Financial } \\
\text { Leverage }\end{array}$ & $\begin{array}{l}\text { EBIT/ } \\
\text { EBIT-Interest }\end{array}$ & DFL & & $\begin{array}{l}\text { Hughes and Mester (2008); } \\
\text { Fiordelisi, Ibanez and Molyneux, } \\
\text { 2010; and Berger and De Young } \\
\text { (1997) }\end{array}$ \\
\hline & $\begin{array}{l}\text { Provision } \\
\text { Coverage }\end{array}$ & $\begin{array}{l}\text { Total Provisions/ } \\
\text { Gross NPL }\end{array}$ & PCR & & Reserve Bank of India Report \\
\hline & $\begin{array}{l}\text { Capital } \\
\text { Adequacy }\end{array}$ & $\begin{array}{l}\text { Tier1 Cap+Tier2 } \\
\text { Cap /Risk Weighted } \\
\text { Assets }\end{array}$ & $\mathrm{CA}$ & & $\begin{array}{l}\text { Petria, Capraru and Ihnatov } \\
\text { (2015); Berger (1995); and } \\
\text { Pilloff and Rhoades (2002) }\end{array}$ \\
\hline & $\begin{array}{l}\text { Return on } \\
\text { Assets }\end{array}$ & $\begin{array}{l}\text { Net Income/ } \\
\text { Total Assets }\end{array}$ & ROA & & $\begin{array}{l}\text { Owlabi and Obida (2012); and } \\
\text { Demirfuc and Detragiache } \\
\text { (1998) }\end{array}$ \\
\hline & Solvency & $\begin{array}{l}\text { Total Debt / } \\
\text { Total Assets }\end{array}$ & SLV & & $\begin{array}{l}\text { Ferrouhi and Agdal, 2014; and } \\
\text { Jackson et.al (2002) }\end{array}$ \\
\hline
\end{tabular}

Abbrev.: abbreviation; Cap: Capital; EBIT: Earnings before interest; NPL: Nonperforming loans; EFF: Efficiency; DFL: Degree of financial leverage; PCR: Provision coverage ratio; CA: Capital adequacy; ROA: Return of assets; SLV: Solvency.

Source: Author

Figure 1: Kernel Density Estimate for Efficiency

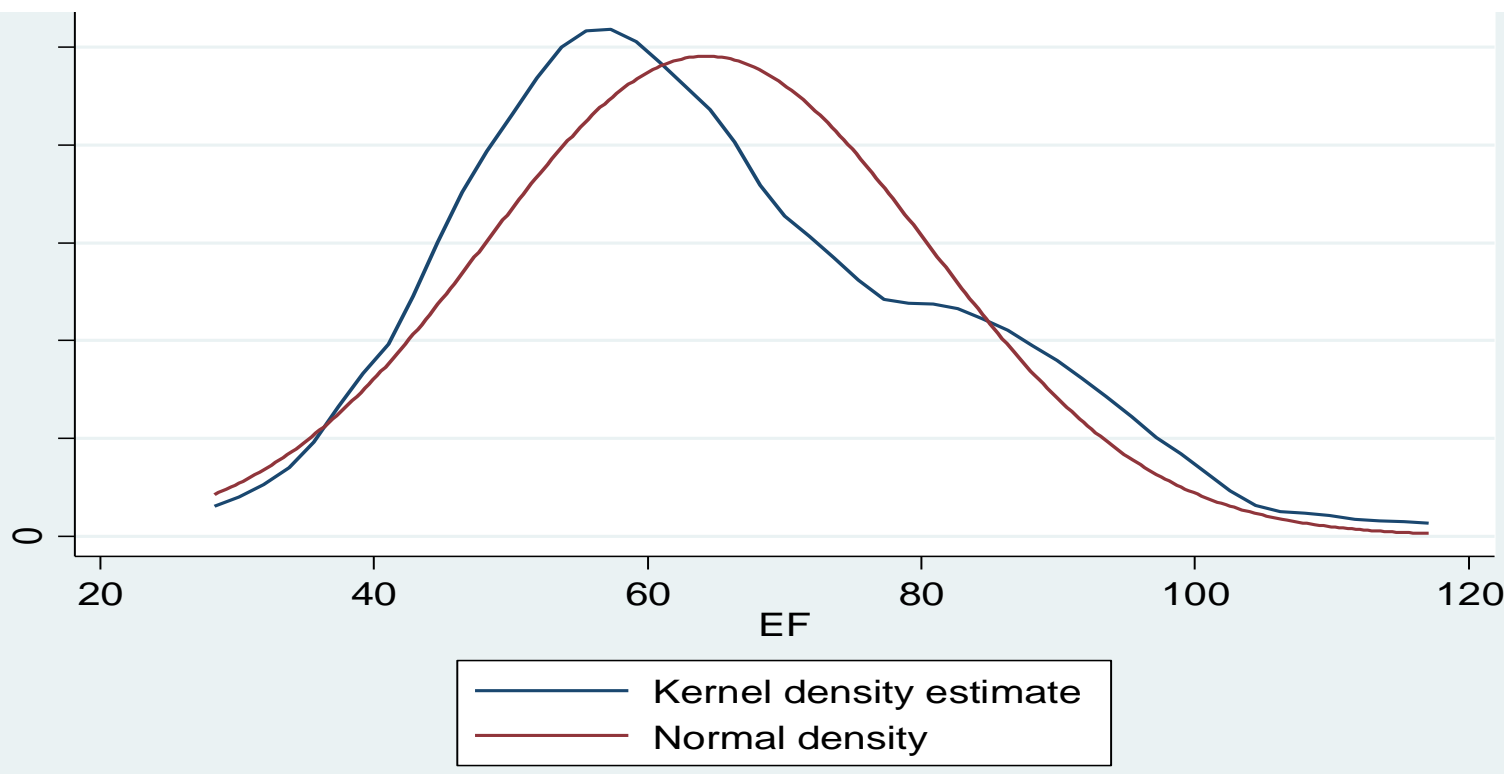

EF: Efficiency factor

Source: Author 
Methodology

A multiple regression analysis was run, using an ordinary-least-square (OLS) analysis. The regression equation is expected to look like equation 2.

Efficiency $=\beta_{0}+\beta_{1} D F L+\beta_{2} P C V R G+\beta_{3} C A+\beta_{4} R O A+\beta_{5}$ Solvency $+\varepsilon$

Where,

$D F L=$ Degree of financial leverage;

$C A=$ Capital adequacy

$R O A=$ Return of assets

The results and findings relating to this equation are presented in the following section.

\section{Main Findings}

This section of the article provides the main findings and a structured examination of the summary statistics, variable correlations, multicollinearity, and regression analysis ${ }^{2}$.

Table 2 lists the descriptive statistics for the variables, including means, standard deviations, and minimum and maximum intervals. It also indicates the data distribution for these variables. As shown in the table, all variables have means very close to the average of the minimum-maximum values, indicating a quasi-normal distribution pattern in each case, as the means are close to the suggested averages.

Table 2: Descriptive Statistics

\begin{tabular}{|l|r|r|r|r|r|}
\hline Variable & Obs. & Mean & Std. Dev & Min & Max \\
\hline Efficiency & 67 & 64.27 & 16.24 & 34.43 & 111.00 \\
\hline Financial Leverage & 67 & -0.14 & 4.54 & -21.97 & 16.96 \\
\hline Provision Coverage & 67 & 11.91 & 11.86 & 2.59 & 44.30 \\
\hline Capital Adequacy & 67 & 19.86 & 8.17 & -8.10 & 42.00 \\
\hline Return on Assets & 67 & 0.99 & 0.54 & -0.14 & 2.07 \\
\hline Solvency & 67 & -0.46 & 1.46 & -4.32 & 1.52 \\
\hline Source: Author & & & \\
\hline
\end{tabular}

In order for a robust analysis, the variables were tested for multicollinearity, which refers to two or more explanatory variables in a multiple regression exhibiting high pairwise correlations. This can lead to inflated standard errors of coefficients and poor significance of estimated coefficients. To check whether our variables exhibited any problematic correlation, a Variance Inflation Factor test was computed (see Table A1). The previous draft analysis included NPLs as an explanatory variable with respect to efficiency, but due to its high multicollinearity, it was excluded from the analysis, resulting in the VIF-values ranging from 1.13 to 1.81. According to Jiao, Koning, Mertens, and Roosenboom (2012), VIF's above five indicate a severe multicollinearity. This indicates that our variables were not strongly correlated with each other and therefore, the regression model would not suffer from multicollinearity.

\footnotetext{
${ }^{2}$ Detailed information regarding pnorm (standardised normal probability P-P), qnorm (quantiles of a normal distribution) and Kernel density distribution estimate are provided in the appendix attached to this article.
} 
Table A1: Variance Inflation Factor (VIF) Test

\begin{tabular}{|l|l|l|}
\hline Variable & VIF & $\mathbf{1}$ VIF \\
\hline Solvency & 1.81 & 0.551 \\
\hline Capital Adequacy & 1.75 & 0.572 \\
\hline Provision Coverage & 1.60 & 0.623 \\
\hline Return on Assets & 1.53 & 0.654 \\
\hline Degree of Financial Leverage & 1.13 & 0.887 \\
\hline MEAN VIF & 1.56 & \\
\hline Source: Authr &
\end{tabular}

Source: Author

Table 3: Spearman Correlation Matrix

\begin{tabular}{|c|c|c|c|c|c|c|}
\hline Variable & Efficiency & $\begin{array}{l}\text { Financial } \\
\text { Leverage }\end{array}$ & $\begin{array}{l}\text { Provision } \\
\text { Coverage } \\
\end{array}$ & $\begin{array}{c}\text { Capital } \\
\text { Adequacy }\end{array}$ & $\begin{array}{c}\text { Return on } \\
\text { Assets }\end{array}$ & Solvency \\
\hline Efficiency & 1.0000 & - & - & & - & - \\
\hline $\begin{array}{l}\text { Financial } \\
\text { Leverage }\end{array}$ & $\begin{array}{c}0.1563 \\
(0.2067)\end{array}$ & 1.0000 & - & & - & - \\
\hline $\begin{array}{l}\text { Provision } \\
\text { Coverage } \\
\end{array}$ & $\begin{array}{c}0.1728 \\
(0.1621) \\
\end{array}$ & $\begin{array}{l}0.5679 * * * \\
(0.0000)\end{array}$ & 1.0000 & & - & - \\
\hline $\begin{array}{l}\text { Capital } \\
\text { Adequacy }\end{array}$ & $\begin{array}{l}-0.5713^{* * * *} \\
(0.0000)\end{array}$ & $\begin{array}{l}-0.2337 * \\
(0.0570)\end{array}$ & $\begin{array}{l}-0.4358 \\
(0.0002)\end{array}$ & 1.0000 & - & - \\
\hline $\begin{array}{l}\text { Return on } \\
\text { Assets }\end{array}$ & $\begin{array}{l}-0.8992 * * * * \\
(0.0000)\end{array}$ & $\begin{array}{l}-0.2638^{* *} \\
(0.0310)\end{array}$ & $\begin{array}{c}-0.3137 * * * \\
(0.0097) \\
\end{array}$ & $\begin{array}{c}0.5147 * * * \\
(0.0000)\end{array}$ & 1.0000 & - \\
\hline Solvency & $\begin{array}{l}02010 \text {. } \\
(0.8719)\end{array}$ & $\begin{array}{c}- \\
0.4243^{* * *} * \\
(0.0003)\end{array}$ & $\begin{array}{c}-0.6959 * * * \\
(0.0000)\end{array}$ & $\begin{array}{c}0.3397 * * * \\
(0.0049)\end{array}$ & $\begin{array}{c}0.1022 \\
(0.4106)\end{array}$ & 1.0000 \\
\hline
\end{tabular}

Table 3 shows the correlation between variables, based on the Spearman Rho coefficient, which is used to measure the strength of the monotonic relationship (the dependence) between variables. A high dependence between variables, indicated by a high correlation, can lead to biased results.

The table 3 shows several variable pairs with statistically significant correlations. Most are weak $(\mid 0.0-$ $0.4 \mid)$ or moderate $(|0.4-0.6|)$, apart from efficiency and ROA, which are strongly correlated $(|0.9|)$. Efficiency negatively correlates with both capital adequacy and ROA. This is because efficiency is calculated as the ratio of expense over revenue and thus affects capital adequacy and performance (which is measured here as ROA). When the efficiency ratio is increasing, expenses are increasing over revenue for the same period, and so capital adequacy and performance would be reducing. This situation poses a concern to the banking system.

During periods when expenses overcome revenues, the operational efficiency of the banks increase, and this consequently leads to a high degree of leverage because the rest of the gap will be covered using debt (increase of financial leverage); at the same time this makes a bank's balance sheet weaker, and reduces the provision coverage.

Also, when the efficiency ratio increases (expenses increasing over revenues) we expect the bank's ability to meet its short- or medium-term obligations to decrease. But the correlation matrix gives us a positive relationship. This may be explained due to the fact that the difference between expenses and revenues is financed by debt, which increases the solvency ratio (total debt/total assets). 
Table 4 summarizes the results of the multiple regression analysis. As indicated in the table, efficiency can be statistically explained by a number of other variables. The variables explaining commercial banks' efficiency in this Albania case are capital adequacy, ROA, and to a lesser degree solvency, indicating that under ceteris paribus conditions, an increase of one unit in capital adequacy may lead to a decrease of 0.051 units into the overall bank efficiency; an increase of one unit in ROA to a decrease of 23 units into the bank efficiency; an increase of one unit is solvency to an increase of slightly less than one unit to banks' efficiency.

Table 4: Results of regression analysis

\begin{tabular}{|c|c|c|c|c|c|c|}
\hline Efficiency & Coef. & St. Error & $t$ & P value & \multicolumn{2}{|c|}{ 95\% Conf. Interval } \\
\hline Financial Leverage & 0.045 & 0.141 & 0.32 & 0.751 & -0.237 & 0.327 \\
\hline Provision Coverage & -0.098 & 0.064 & -1.51 & 0.135 & -0.227 & 0.031 \\
\hline Capital Adequacy & $-0.051 * * *$ & 0.097 & -5.21 & 0.000 & -0.704 & -0.313 \\
\hline Return on Assets & $-23.820 * * *$ & 1.359 & -17.52 & 0.000 & -26.541 & -21.103 \\
\hline Solvency & $0.955^{*}$ & 0.557 & 1.72 & 0.091 & -0.158 & 2.069 \\
\hline Const. & $99.764 * * *$ & 1.927 & 51.77 & 0.000 & 96.911 & 103.617 \\
\hline \multicolumn{7}{|c|}{ No. of observations: 67} \\
\hline \multicolumn{7}{|l|}{ R Square: 0.90} \\
\hline \multicolumn{7}{|l|}{$F(5,61)=132.31$} \\
\hline \multicolumn{7}{|l|}{ Prob $>F=0.0000$} \\
\hline \multicolumn{7}{|c|}{ Rho Coefficient and $P$ values in parenthesis. * significant at $10 \%, * *$ significant at $5 \%, * * *$ significant at $1 \%$} \\
\hline \multicolumn{7}{|l|}{ Source: Author } \\
\hline
\end{tabular}

No conclusion can be drawn for financial leverage and provision coverage, due to coefficients that were statistically insignificant.

Therefore, the following efficiency's function is proposed:

Efficiency $=f($ Capital Adequacy, Return on Assets, Solvency $)$

This results in the following (Equation 3):

Efficiency $=99.7-0.05 C A-23.8$ ROA +0.09 Solvency $+\varepsilon$

Where,

$C A=$ Capital adequacy

$R O A=$ Return of assets

Therefore, an increase in efficiency (which is explained by an increase in expenses compared to revenues) reduces the capital adequacy ratio because the risk of the bank increases compared to its capital. At the same time, an increase in efficiency reduces performance (ROA) because net income decreases and therefore the ratio of ROA (net income / total assets) decreases. As explained before, the positive correlation between solvency and efficiency can be attributed to the deficit in revenue meeting expenses that can be financed by debt, and which increases the solvency.

\section{Conclusion}

It can be concluded that the efficiency of commercial banks in Albania is significantly affected by capital adequacy, return on assets, and solvency. In order to lower the efficiency (i.e. increase revenue over expenses) in the Albanian banking system, the Central Bank needs to take action to reduce solvency by lowering debt and increasing assets, which will increase the asset portfolio and decrease the debt level. In terms of efficiency, Albanian banks should try to reduce expenses and increase the revenue for the same period of time. These significant results lead to the acceptance of the tested hypothesis. 


\section{References}

Abbasoglu, F. O., Aysan, F.A. \& Gunes, A. (2007). "Concentration, Competition, Efficiency And Profitability of the Turkish Banking Sector in the Post-Crisis Period". Banks and Bank Systems, Vol 2, Issue 3. pp 106- 115.

Berger, A. N. \& Humprey.B., (1997). Efficiency of Financial Institutions: International survey and directions for future research, European Journal of Operations Research, 98, 175- 212.

Berger, A.N. (1995). The Profit-Structure Relationship in banking- Tests of Market Power and Efficient-Structure Hypotheses, Journal of Money, Credit and Banking, Vol.27,N.2, pp.404-431.

Berger, A.N., De Young R. (1997). Problem loans and cost efficiency in commercial banking. Journal of Banking and Finance 21, 849-870.

Casu, B. \& Girardone, C. (2009). Testing the relationship between competition and efficiency in banking: A panel data analysis. Economics Letters 105, 134-137.

Demirgüç, K. \& Detragiache, E. (2005). Cross Country Empirical Studies of Systemic Bank Distress:A Survey, IMF Working Paper.

Ferrouhi, M. \& Agdal, M. (2014). "Liquidity and Solcency in the International Banking Regulation," Paper presented in The Clue Institute: International Academic Conference. Germany.

Fiordelisi, F., Ibanez, M. D. \& Molyneux, P. (2010). "Efficiency and Risk in European Banking”. European Central Bank Working Paper Series, No 1211.

Hughes, P. J., \& Mester, J. L. (2008). "Efficiency in Banking: Theory, Practice and Evidence”, Oxford Handbook of Banking.

Jackson, P., Perraudin, W., \& Saporta, V. (2002). Regulatory and economic solvency standards for internationally active banks. (Bank of England working papers, $\mathrm{N}^{\circ} 161$ ). Bank of England.

Jiao, T., Koning, M., Mertens, G. \& Roosenboom, P. (2012). Mandatory IFRS adoption and its impact on analysts' forecasts. International Review of Financial Analysis, No.21, pp. 56-63.

Miencha, I. O. \& Selvam, M. (2013). Operational Efficiency and Profitability of Kenyan Commercial Banks (October 4, 2013). Available at SSRN: http://ssrn.com/abstract=2335851

Oral, M. \& Yolalan, R. (1990). “ An empirical study on measuring operating efficiency and profitability of bank branches". European Journal of Operational Research. Vol 46, Issue 3. Pp 282-294).

Owolabi, S. A. \& Obida, S. S, (2012), Business Management Dynamics, Vol.2, No. 2, pp 10-25.

Owolabi, O. A., Sadiq, M.O. \& Abiola, S. O. (2012). "Development of Performance Models for a Typical Flexible road Pavement in Nigeria". International Journal for Traffic and Transport Engineering. Vol 2, Issue 3: pp 178-184.

Petria, N., Capraru, B. \& Ihnatov, I. (2015). "Determinants of banks' profitability: evidence from EU 27 banking systems," Paper presented at $7^{\text {th }}$ International Conference on Globalization and Higher Education in Economics and Business Administration, GEBA 2013. Published by Elsevier. Available at ISSN 2212-5671.

Pilloff, J., S. \& Rhoades, A.,S. (2002). "Structure and Profitability in Banking Markets". Review of Industrial Organization 20. Netherlands, Pp 81-92.

Schneide, F. \& Lenzelbaue, W. (1993). "An Inverse Relationship between Efficiency and Profitability According to Size of Austrian Firms? Some Further Tentative Results. Small Business Economics, Vol 5, No 1. Pp 1-22. 


\section{Appendix}

\section{Table A.2 Probability and Quartile Plot}

The P-Norm exhibits the standardized normal probability plot and is sensitive to the lack of normality within the middle of the range of the distribution. As shown in the left graph below there is no indication of non-normality. Meanwhile Q-Norm (the graph on the right) plots the quartiles of a variable against the quartiles of a normal distribution and is mainly sensitive to non-normality near the tails. As shown in the graph the distribution of the quartiles is almost very close to the normal distribution. It is accepted that the residuals are close to a normal distribution.

\begin{tabular}{|lll|l|l|}
\hline Table A.2 a) & Table A.2 b) \\
\hline 8 & & & \\
\hline Source: Author & & & & \\
\hline
\end{tabular}

